\title{
GAYA HIDUP HEDONIS DALAM NOVEL IN BED WITH MODEL\$ KARYA MOAMMAR EMKA
}

\author{
Dafir Hisabah dan Ali Nuke Affandy \\ Pendidikan Bahasa dan Sastra Indonesia, Universitas Muhammadiyah Surabaya \\ dafirhisabah2@gmail.com
}

\begin{abstract}
ABSTRAK
Fokus penelitian ini adalah (1) Gaya hidup dalam hal hiburan pada tokoh dalam novel In Bed With Model\$ karya Moammar Emka, (2) Gaya hidup dalam hal berpakaian pada tokoh dalam novel In Bed With Model\$ karya Moammar Emka dan (3) Gaya Hidup dalam hal makanan pada tokoh dalam novel In Bed With Model\$ karya Moammar Emka. Metode penelitian yang digunakan adalah menggunakan metode dan pendekatan deskriptif-kualitatif. Sumber data penelitian ini menguraikan data yang berbentuk kata-kata tentang gaya hidup hedonis pada novel In Bed With Model\$ sedangkan objek penelitian yaitu berupa teks atau dialog kata, dan kalimat mengenai gaya hidup yang ada pada novel. Pengumpulan data yang digunakan adalah teknik dokumentasi. Teknik analisis data dengan menggunakan reduksi data, penyajian data dan penarikan simpulan. Hasil penelitian ini menunjukkan bahwa (1) gaya hidup dalam hal hiburan yang dialami para tokoh dilihat dari perilaku seorang model dalam hidupnya selalu memasuki tempat hiburan malam seperti cafe dan diskotik, (2) gaya hidup dalam hal pakaian pada tokoh seorang model memilih menggunakan pakaian bermerek, baju yang sedikit memperlihatkan sebagian tubuhnya dan digunakan setiap hari ke tempat hiburan malam (3) gaya hidup dalam hal makanan dari kesehariaan tokoh selalu mengkonsumsi makanan yang serba mewah dan minuman beralkohol dengan harga mahal yang terdapat pada cafe, restoran dan tempat hiburan malam.
\end{abstract}

Kata kunci: Gaya Hidup Hedonis, Hiburan, Pakaian, Makanan

\section{ABSTRACT}

The focus of this research was lifestyle in terms of (1) entertainment, (2), and (3) food in character of novel entitled in Bed With Model by Moammar Emka. The research method used was descriptive-qualitative methods and approaches. The source of this research was described data in the form of words about the hedonic lifestyle in the novel entitled in Bed With Model \$, while the object of research was in the form of text or dialogue, and sentences about the lifestyle that existed in the novel. Data collection used was documentation technique. Data analysis techniques used data reduction, data presentation, and drawing conclusions. The results of this study indicated that (1) lifestyle in terms of entertainment experienced by the characters seen from the model entering nightlife places such as cafes and discotheques, (2) lifestyle in terms of clothing showed from the character as a model were used to use branded clothes, sexy clothes that showed their body and used to go to nightclubs everyday (3) lifestyle in terms of food were described from everyday 
life of characters who always consumed fancy foods and alcoholic drinks at high prices found in cafes, restaurants, and nightclubs.

Keywords: Hedonistic Lifestyle, Entertainment, Cloth, Food

\section{PENDAHULUAN}

Media sosial menyuguhkan beberapa hal informasi seperti berita sosial, gaya hidup, ekonomi, dan lain sebagainya, seperti halnya penawaran iklan mengenai berbagai produk kecantikan yang secara sadar membius masyarakat. Kaum remaja yang masih labil menjadi sasaran utama pada produsen untuk menjadikan model dari produk-produk terkenal ini. Tidak heran jika budaya konsumtif sudah melekat dari diri masyarakat. Hal tersebut dikuatkan lagi dengan budaya hedonisme pada masyarakat saat ini. Hedonisme sendiri adalah pandangan yang menganggap kesenangan dan kenikmatan materi sebagai tujuan utama hidup. Sebuah kebiasaan yang realitanya menghancurkan tatanan masyarakat yang ada. Munculnya budaya hedonisme ini terjadi tanpa kita sadari seiring dengan perkembangan zaman yang semakin modern. Gaya hidup yang glamor semakin melekat pada diri remaja, seakan ada istilah ga' style itu ga' zaman gan!!. Mereka yang sudah tergila-gila dengan budaya konsumtif akan rela melakukan apa saja demi memenuhi keinginannya. Seperti halnya mencari model baju yang mengikuti fashion terbaru, jam tangan, sepatu bermerek, tas mahal bahkan dari ujung rambut sampai ujung kaki pun tak luput menjadi saksi bisu budaya. Keinginan hidup memang menjadi daya tarik tersendiri pada remaja di zaman modern ini. Faktor penyebab kemunculan budaya hedonisme yaitu sikap individualis atau sikap egois yang tinggi dan sifat psikologi dari remaja itu sendiri (www.compasiana.com).

Gaya hidup merupakan salah satu kebutuhan yang ada dalam suatu kelompok masyarakat. Salah satu diantaranya, yaitu para model dan artis yang berkiprah di dunia hiburan. Gaya hidup yang serba mewah selalu melekat pada diri seorang model dan artis yang selalu menjaga penampilan. Mereka sering mengoleksi barang-barang mewah yang mengikuti trend, tinggal di tempat yang bagus, makan-makanan di tempat yang mahal dan sering menghabiskan uang dengan teman-temannya di tempat hiburan malam dan cafe yang mahal. Gaya hidup seperti inilah merupakan gaya hidup hedonis. 
Seseorang yang menganut paham hedonis adalah seorang dari kalangan artis dan modelis yang sangat memprioritaskan gaya hidup mereka yang serba mewah dan glamor dalam mempertahankan prioritas kehidupannya. Sebagian dari mereka rela mengorbankan segala hal untuk mempertahankan gaya hidupnya. Seseorang yang memiliki gaya hidup hedonis biasanya memiliki tempat tinggal yang mewah, pakaian yang serba mewah dan glamor, transportasi mewah, serta barang-barang atau perhiasan yang brend. Penampilan dalam setiap harinya selalu mengikuti tren terbaru dan tampil glamor baik dari barang yang dipakai dan baju yang digunakan. Selain itu, biasanya mereka makan/nongkrong di tempat yang mewah seperti cafe, restoran mahal dan club bersama temannya.

Novel In Bed With Model\$ merupakan novel yang menuai kisah para selebritas dan model mulai dari selebritas papan atas, model catwalk, model escort, model iklan, dan model sinetron. Novel ini hanya membahas tentang seorang model dari 5 sampai 15 orang. Kata model\$ yang menggunakan simbol $\$=$ dolar sebagai satu bentuk penggambaran bahwa sisi-sisi gelap sebagian model dan rahasia dari sejumlah model melibatkan unsur uang di dalamnya. Kehidupan seorang model tentu tidak lepas dari sisi positif dan negatif dalam keseharian. Sisi positif seorang model sudah tentu banyak pelajaran yang bisa ditiru dan diambil manfaatnya, dan dari sisi negatif seorang model bukan berarti tidak ada celah positif yang bisa di jadikan informasi berharga, tetapi ada rahasia kehidupan seorang model yang tidak pernah diketahui sebelumnya dan mungkin bisa menginspirasi banyak orang. Salah satu cara seseorang untuk menuju popularitasnya yaitu sebagai model yang dipilih melalui casting, berani tampil seksi, jadi selingkuhan, bahkan melakukan free sex. Sisi-sisi seperti itulah yang ingin diungkapkan penulis dalam novel ini.

Salah satu tokoh yang ada dalam novel tersebut ialah Sarah, Sarah pernah berkiprah di dunia model di Indonesia sejak SMA dan berkiprah di dunia model dengan paras dan sepasang mata kucing yang bisa membuat pria terpesona oleh kecantikannya. Setelah kembali ke Indonesia, sarah mencoba kariernya sebagai modeling dan ia juga tak keberatan untuk kencan dan melayani nafsu seksual pria yang umurnya dua puluh tahun lebih tua dari sarah untuk mempertahankan gaya hidupnya yang serba mewah. Gaya hidup model yang ada dalam novel ini sangat cenderung pada kenikmatan hidup semata yang sesuai dengan gaya hidup hedonisme. 
Menurut Susanto dalam Wulandari (2014: 21) menyatakan bahwa hedonis adalah sebagai sesuatu yang dianggap baik bila mengandung kenikmatan bagi manusia. Namun, kaum hedonis memiliki kata kesenangan menjadi kebahagiaan. Seseorang yang menganut gaya hidup hedonis memiliki ciri khas yaitu kebahagiaan diperoleh dengan cara mencari perasaan-perasaan yang menyenangkan dan selalu ingin menghindari kemungkinan perasaan-perasaan yang tidak baik.

Ariani (2010: 12) menjelaskan lebih lanjut mengenai hedonisme bahwa individu yang memiliki gaya hidup hedonis biasanya selalu ingin memiliki keterlibatan yang tinggi dengan orang lain dan selalu cenderung menyukai kegiatan yang bersifat menyenangkan daripada kegiatan sosial, tidak terlalu serius dalam segala hal dan selalu senang dengan keramaian. Selain itu, ciri-ciri manusia yang menganut paham hedonis yaitu selalu mengarahkan kepada aktivitas dengan tujuan untuk mencapai kenikmatan hidupnya dan sebagian besar perhatiannya ditujukan diluar rumah, orientasinya eksternal, selalu selektif dalam mencari teman, ingin menjadi pusat perhatian semua orang, waktu luang hanya untuk bermain dan bersenang-senang, kebanyakan anggota kelompok tersebut yaitu orang berada. Berdasarkan pemaparan dari cerita novel In Bed With Model\$ maka peneliti tertarik untuk menganalisis gaya hidup tokoh yang ada di dalam novel In Bed With Model\$ dengan teori Hedonisme.

\section{METODE PENELITIAN}

Penelitian ini menggunakan Pendekatan deskriptif kualitatif yaitu suatu prosedur penelitian dengan hasil sajian data deskriptif berupa tuturan pengarang pada novel In Bed With Model\$ karya Moammar Emka. Mahsun (2005: 37) mengungkapkan metode deskriptif-kualitatif adalah suatu prosedur penelitian yang menggunakan data deskriptif berupa kata-kata tertulis atau lisan dari orang-orang dan pelaku yang dapat diamati. Sumber data dalam penelitian ini merupakan semua data yang ada dalam sarana penelitian yang bersifat objektif dan harus jelas berdasarkan fokus penelitian. Sumber data dalam penelitian ini adalah novel In Bed With Model\$ karya Moammar Emka. Objek penelitian ini adalah teks atau dialog kata, dan kalimat yang terdapat pada novel In Bed With Model\$ karya Moammar Emka.

Teknik pengumpulan data yang digunakan pada penelitian ini menggunakan metode dokumentasi, dengan mencari serta mengumpukan data-data yang dibutuhkan 
dalam bentuk kalimat atau kata-kata yang berhubungan dengan gaya hidup hedonis pada novel In Bed With Model\$ karya Moammar Emka. Arikunto (2010: 274) mengatakan bahwa metode dokumentasi adalah mencari data mengenai hal-hal atau variabel yang berupa catatan, transkip, buku, surat kabar, majalah, prasasti, notulen rapat, lengger, agenda dan sebagainya. Dalam hal ini peneliti mencari dan mengumpulkan data-data yang terkait dengan gaya hidup hedonis pada novel yang berjudul In Bed With Model\$ karya Moammar Emka dengan cara membaca keseluruhan isi novel dengan seksama. Peneliti mencatat data yang ditemukan dalam novel yang akan dibahas untuk dianalisis.

Teknik analisis data yang digunakan dalam penelitian ini adalah metode deskripsi. Metode deskripsi dilakukan melalui pengumpulan data yang disusun, dianalisis, diklasifikasikan, dibahas, dan disimpulkan. Menurut Sugiyono (2014: 247253) langkah-langkah dalam menganalisis novel In Bed With Model\$ karya Moammar Emka dengan cara sebagai berikut :

1. Reduksi data, yakni dengan cara mengelompokkan data sesuai dengan ciri tertentu. Memilih hal pokok yang penting yang menjadi fokus penelitian.

2. Penyajian data, yakni teknik dalam penyajian data dengan bentuk grafik, tabel, ataupun sejenisnya dimana didalamnya tersaji data-data kategorisasi.

3. Penarikan kesimpulan, yakni memaknai, menyimpulkan, dan membandingkan data-data yang telah dikategorikan sebelumnya dan ditemukan dalam novel In Bed With Model\$ karya Moammar Emka dengan menggunakan data yang membahas tentang gaya hidup para model dalam sehari-sehari

\section{PEMBAHASAN}

Secara umum gaya hidup hedonis tidak bisa dilepaskan dari budaya yang berkembang saat ini serta menyertai persoalan kehidupan termasuk dalam dunia sastra. Kaum hedonis akan melakukan hal apapun demi memperoleh sebuah kesenangan, seperti yang dicontohkan dalam novel In Bed With Model\$ karya Moammar Emka bahwa seorang wanita rela menjadi model majalah dewasa dan menjadi cewek simpanan laki-laki berduit untuk mendapatkan uang tambahan. Hedonisme di dalam novel ini sangat terlihat jelas, mulai dari mengejar kenikmatan seks, kenikmatan harta serta popularitas. Cerita dalam novel ini merupakan cerita 
yang diambil dari kisah nyata, oleh sebab itu tidak menutup kemungkinan kita akan sering menemukan kejadian-kejadian seperti yang ada pada novel tersebut, misalnya bergaya mewah-mewahan untuk mendapatkan kesenangan semata atau melakukan seks bebas, kesenangan semacam itu sudah menjadi hal yang wajar di kalangan masyarakat perkotaan.

\section{Gaya Hidup dalam Hal Hiburan}

Gaya hidup menggambarkan diri seseorang dalam berinteraksi dengan lingkungannya, menggambarkan tingkah laku seseorang dalam beraksi dan berinteraksi dalam masyarakat. Salah satu gaya hidup yang terjadi yaitu pada hal hiburan dimana para model yang ada lebih sering melakukan hal-hal yang berbau duniawi seperti hanya kutipan berikut.

"Sexy for you adalah salah satunya. Dari temanya saja, sudah terbayang dikepala bakal seperti apa isi acaranya. Yang pasti, jualan utamanya: tontonan liar dengan subyek seksi. Pokoknya, adult-contents dan hanya diperuntukkan bagi kalangan yang berumur 21+”.

(IBWM/GHH/Emka,2014:15)

Manusia memiliki kepribadian yang berbeda dalam menjalankan hidupnya. Setiap orang memiliki sifat berbeda dengan orang lain, seperti halnya manusia memiliki kebebasan tersendiri. Dia dapat menentukan sendiri apa yang dapat dilakukannya. Dia dapat mengambil sikap untuk menyesuaikan diriya dengan lingkungan sekitarnya atau pun dia bertindak melawan lingkungannya. Manusia bebas melakukan apa yang ingin dicapai, dilakukan dalam hidupnya, tidak ada keterikatan dalam setiap diri manusia. Dia bebas menentukan dan memutuskan sendiri tindakan dan pilihan yang diambil dalam hidupnya.

Para model atau artis yang ingin melakukan suatu hal dalam melangsungkan hidupnya memilih jalan masing-masing diantaranya melakukan suatu hal yang menantang dalam hidupnya. Salah satu hal dengan menjadi model majalah dewasa, artis dan juga menemani laki-laki berduit di tempat-tempat hiburan malam. Hal ini sesuai dengan kutipan sebagai berikut :

“Jadilah malam ini, sesuai dengan kesepakatan, saya meluncur kesebuah tempat hiburan malam di kawasan Gatot Subroto. Lokasi hiburan malam 
tempat kami berjanji untuk ketemu terletak di lantai paling atas salah satu gedung. Biasanya, tempat itu baru mulai dipenuhi pengunjung pukul sebelas ke atas. Saya janji bertemu Beni pukul sepuluh. Suasana di lounge-nya masih terlihat sepi. Beberapa kursi sofa yang paling berjarak agak jauh antara satu dengan yang lain masih banyak yang kosong. Seorang DJ sedang asik menggesek-gesekkan piringan hitamnya dengan stylus sehingga menghasilkan musik menghentak tepat di stage yang ada di tengah-tengah floor”.

(IBWM/GHH/Emka,2014:57)

Tempat-tempat malam merupakan salah satu tempat para model dan laki-laki berduit yang ingin bersenang-senang semata, dimana mereka menghabiskan waktunya sepanjang malam dengan om-om yang membayar para model untuk menemaninya. Suasana tempat yang mereka datangi lebih tertutup dan hanya pada malam hari, diiringi musik yang dimainkan seorang DJ. Selain itu terdapat para model yang menari di untuk menarik perhatian para laki-laki berduit yang berada di pada tempat tersebut.

Salah satu kota yang memiliki tempat-tempat hiburan malam yaitu kota Jakarta. Kota Jakarta merupakan kota yang cenderung hedonisme didunia dan dikenal dengan kota metropolitan. Gaya hidup hedonisme inilah yang meraja lela dikota tersebut karena pergaulan dan kebutuhan hidup yang keras sehingga menjadikan para model melakukan aksi sensualitas sebagai daya tarik tersendiri di tempat hiburan malam. Adapun halnya kutipan sebagai berikut.

"Tempat hiburan malam di jakarta, rata-rata menjual sensualitas sebagai daya tarik untuk membuat tamu datang. Kalau ada orang bilang, malam-malam di jakarta, baunya tak lepas dari aroma sensualitas, memang ada benarnya. Tak heran, sensualitas kini jadi identik dunia hiburan. Tentu saja, ini menjadi lahan emas bagi “artis pendukung” dan pengusaha di bisnis kesenangan”.

(IBWM/GHH/Emka,2014:125)

Kota Jakarta merupakan kota terbesar di Indonesia, selain terbesar kota tersebut sudah terkenal dengan pergaulannya yang luas dan tempat hiburan malamnya yang terkenal bagi para lelaki yang berduit dan para artis pendukung, tak heran banyak artis yang memanfaatkan tempat hiburan untuk mencari job tambahan selain menjadi artis juga di manfaatkan para pengusaha yang kesenangannya di dunia hiburan. 


\section{Gaya Hidup dalam Hal Berpakaian}

Penampilan pada seorang model merupakan hal yang utama, karena dengan berpenampilan yang seksi dan cantik dengan mudah dapat menarik perhatian laki-laki berduit. Penampilan seorang model dilihat dari ujung rambut sampai ujung kaki, misalnya baju yang dipakai, sepatu, tatanan rambut dan make up yang bagus dengan barang-barang mahal yang digunakan. Seorang model dalam melayani laki-laki berduit biasanya berpenampilan yang agak terbuka, seperti halnya kutipan berikut.

“Kedua wanita cantik mengenakan tank top tali spaghetti itu menyalami saya. Kaki sarah yang jenjang dibalut miniskirt berbahan jeans, sementara jesika menggunakan rok berbahan silver. Beni juga tau kalau Sarah dan Jesika adalah model”.

(IBWM/GHP/Emka,2014:58)

Kehidupan seorang model tidak lepas dari pakaian yang sedikit terbuka, hal ini terjadi pada beberapa tokoh yang ada dalam novel ini yaitu Sarah dan Jesika. Mereka seringkali menggunakan pakaian yang agak terbuka ketika pergi ke tempat hiburan malam dimana mereka bertemu dengan laki-laki berduit, menghabiskan malam secara bersama dan bersenang-senang.

Penampilan yang membiarkan sebagian tubuhnya terbuka identik dengan model, baik dari baju yang digunakan maupun bawahan seperti rok pendek. Kebiasaankebiasan yang diterapkan model ini menjadi kebudayaan yang timbul diantara kalangan model dan artis. Penampilan tersebut ditunjang untuk mencari perhatian para laki-laki berduit. Seperti halnya kutipan berikut.

"Venie yang berpostur $170 \mathrm{~cm}$ tetap menggunakan hi-heels dengan celana jeans dan atasan "u can see" kaos tanpa lengan. Klara membiarkan bagian tubuhnya terbuka. Sementara Sandra menggunakan rok mini dengan kaos tank top yang memperlihatkan bagian pusarnya yang ditindik”.

(IBWM/GHP/Emka, 2014:95-96)

Beberapa tokoh yang ada dalam novel berpakaian sedikit terbuka dengan membiarkan bagian tubuhnya terbuka, salah satunya menggunakan tank top yang memperlihatkan bagian pusarnya dan memakai rok mini disertai dengan menggunakan hi-heels ketika pergi ketempat hiburan yang biasa di datangi para model dan artis. 
Kutipan selanjutnya masih ada kesamaan dengan kutipan sebelumnya. Model yang berpenampilan seksi dan terbuka dimulai dari mengikuti casting model majalah dewasa yang dituntut untuk berani dalam melakukan photoshoot dan menguti acara fashion show yang diadakan beberapa desainer pakaian seksi. Kutipannya sebagai berikut.

"Industri hiburan, sinetron, film, iklan, dan media cetak pun tak lepas dari unsur perilaku ekshibisionis ini. Sejumlah artis yang berani memerankan tokoh-tokohnya dengan mengenakan pakaian minim dan seksi, bahkan tak jarang mengumbar bagian sex-appeal tubuh. Begitu juga kalangan foto model yang terbiasa berpose "nekad" di majalah atau tabloid. Atau beberapa antraksi fashion show yang tak kalah panas mengumbar keindahan tubuh".

(IBWM/GHP/Emka, 2014:121)

Perjalanan seorang model untuk mencapai kesuksesannya tidakla mudah. Melainkan ada bebarapa tahapan yang harus dilakukan, misalnya pada kutipan diatas menjadi foto model dewasa yang ada di majalah serta melakukan fashion show yang mengumbar beberapa bagian tubuhnya. Setelah menggeluti profesinya sebagai model tidak menjamin seseorang akan hidup mewah, oleh karena itu beberapa model rela mengorbankan dirinya demi memenuhi kebutuhan hidupnya.

\section{Gaya Hidup dalam Hal Makanan}

Para model rela melakukan apa saja untuk manarik perhatian laki-laki berduit, salah satu diantara dengan melayani dalam memberikan minuman yang terdapat pada tempat tersebut. Minuman yang sering dikonsumsi oleh pengunjung di tempat tersebut yaitu aneka minuman beralkohol. Seperti halnya pada kutipan sebagai berikut.

"Di atas meja disediakan berbagai macam botol minuman beralkohol. Whisky, wine, vodka, semua ada. Tinggal racik dan tuang sendiri, dan silahkan diminum sepuasnya. Mereka yang tak mau repot, tinggal menenggal langsung dari botol atau dilayani sejumlah gadis under-wear yang dengan hati akan menuangkan minuman”.

(IBWM/GHM/Emka,2014:43)

Pada tempat hiburan malam tidak hanya terdapat model cantik dan seksi, lakilaki berduit melainkan terdapat beberapa jenis minuman beralkohol yang disediakan 
untuk para tamu yang datang pada tempat tersebut. Para model yang seringkali menemani laki-laki berduit tidak hanya menemani semata, melainkan melayani kemauan yang diminta seperti pada kutipan diatas menuangkan minuman tersebut untuk mendapat perhatian lebih dari klien sehingga membuat klien akan tertarik untuk mengunjungi kembali tempat tersebut.

Kutipan selanjutnya masih ada kesamaan dengan kutipan sebelumnya. Gaya hidup para model dilihat dari makanan dan minuman yang sering mereka konsumsi setiap hari. Salah satu contoh minuman yang sering dikonsumsi oleh para model yaitu minuman yang berbau alkohol, seperti hanya pada kutipan sebagai berikut.

"Hingar-bingar dibar VE masih terus berlangsung. Clara sudah menghabiskan tiga gelas Flaming bikini. Venie dan Sandra saling berlomba meminum Vodka Cranberry. Saya sudah menghabiskan sedikitnya empat gelas White-Russian campuran Vodka, Kahlua dan susu”.

(BWM/GHM/Emka,2014:99)

Gaya hidup pada beberapa tokoh dalam kutipan diatas menggambarkan kesenangan semata. Para model berlomba-lomba dalam menghabiskan minuman yang tersedia pada tempat tersebut dengan jenis minuman yang bervariasi seperti pada tokoh Clara, Venie dan Sandra. Hal ini disebakan karena kebiasaan para model dalam mengkonsumsi minuman tersebut ketika berada di tempat hiburan malam tanpa melihat efek samping dari minuman yang dia konsumsi.

Model yang berkerja pada hiburan malam dengan menemani laki-laki berduit ada sebagian hanya menamani makan di kafe atau restauran mahal dan karaoke saja, tanpa melakukan hubungan yang lebih lanjut baik berupa sentuhan sampai melakukan hubungan seks dengan laki-laki yang menemaninya. Seperti halnya pada kutipan sebagai berikut :

"Selain menerapkan display di cafe mal, Tata juga mengatur beberapa modelnya untuk bertugas sebagai lady companion. Acaranya, sekedar menemani lunch atau diner laki-laki berduit, atau menemani berkaraoke, sampai liburan, Tidak melulu harus melibatkan transaksi seks. Kadangkadang, beberapa pelanggan yang mem-booking Rere misalnya, hanya perlu ditemani makan malam dan berkaraoke saja, tak lebih. Tapi, yang meminta pelesir lanjutan dengan kencan di hotel untuk one nite stand, juga tak kalah banyak".

(BWM/GHM/Emka,2014:179) 
Beberapa model hanya melayani makan siang dan malam kliennya di cafe, menamani karaoke dan liburan tanpa melakukan seks dengan laki-laki tersebut. Hal ini terjadi pada tokoh Rere yang ada pada novel. Akan tetapi yang melakukan lebih dari itu juga banyak terjadi pada model-model yang ingin mendapatkan bonus tambahan dari klien tersebut.

\section{PENUTUP}

Berdasarkan analisis data simpulannya adalah gaya hidup yang dialami para tokoh yang ada dalam novel In Bed With Model\$ karya Moammar Emka yaitu gaya hidup dalam hal hiburan, pakaian dan makanan. Perilaku model dakam novel ini dalam menjalankan kehidupannya dengan tujuan utama bersenang-senang semata dengan mengunjungi tempat-tempat hiburan malam, selalu berpakaian dan menggunakan yang mengikuti trend dengan merek yang mahal. Selain itu, selalu makan di tempat-tempat yang mahal seperti cafe dan restoran mahal, selalu berbenja di mall dengan menghabiskan waktunya dengan teman-temannya.

\section{DAFTAR PUSTAKA}

Ariani, D. 2010. Gaya Hidup Mahasiswi (Studi Kasus di Pondokan Arafah Kelurahan Simpang Baru Kecamatan Tampan Pekanbaru). Skripsi. Riau : Universitas Riau

Arikunto, S. 2010. Prosedur Penelitian Suatu Pendekatan Praktek. Jakarta: PT. Rineka Cipta.

Mahsun. 2005. Metode Penelitian Bahasa. Jakarta : Rajagrafindo Persada

Oktaviani, Ledya. 2017. Media Sosial Suatu Fenomena yang Mengubah Gaya Hidup (online). Diakses dari http://www.compasiana.com Juli, 18, 2018

Sugiyono. 2014. Metode Penelitian Pendidikan Pendekatan Kuantitatif, Kualitatif, dan $R \& D$. Bandung: Alfabeta

Wulandari, Euis. 2014. Fenomena Gaya Berbusana Di Kalangan Remaja Hedonis. Lampung : Fakultas Ilmu Sosial dan Ilmu Politik UNILA 